\title{
7. Using soil geochemistry to investigate gold and base metal distribution and dispersal in the glaciated north of Ireland
}

\author{
Michael Dempster, ${ }^{1}$ Mark Cooper, ${ }^{2}$ Paul Dunlop ${ }^{\mathrm{I}}$ And \\ Andreas Scheib 3
}

How to cite this chapter:

Dempster, M., Cooper, M.R., Dunlop, P. and Scheib, A.J., 2016 'Using soil geochemistry

to investigate gold and

base metal distribution and dispersal in the glaciated north

of Ireland' in M.E. Young

(ed.), Unearthed: impacts of

the Tellus surveys of the north

of Ireland. Dublin. Royal Irish

Academy.

DOI:10.3318/

978-1-908996-88-6.ch7
Soil geochemistry is routinely and effectively used for mineral prospecting in areas of glaciated terrain, notably in Canada and Finland. This study uses the Tellus and Tellus Border soil geochemical data to investigate possible glacial dispersal of gold and base metals in the Down-Longford terrane of Ireland. Results from multivariate statistical analysis of the data correlate well with known mineralisation and prove effective in identifying further areas of potentially high prospectivity. Dispersal of gold and base metals is identified, reflecting single and multiple ice flow directions over relatively short distances $(\leq 20 \mathrm{~km})$.

\section{INTRODUCTION}

Gold and base metals have been found in various geological environments in the north of Ireland (Arthurs and Earls, 2004). An important host region is the Southern Uplands - Down-Longford (SUDL) terrane, which is composed of greywacke sandstone and mudstone turbidite sequences arranged in fault-bound tracts (Anderson, 2004) (Fig. 7.1). In the past, base metal deposits have been worked most notably in the South Armagh-Monaghan mining district and at the Conlig-Whitespots lead mine in north County Down. Gold also occurs in various geological settings in the SUDL terrane in Scotland and the Republic of Ireland.

A prospectivity analysis using Tellus soil geochemistry for the Northern Ireland outcrop of the SUDL terrane (Lusty et al., 2012) identified areas that warrant further prospecting in strata to the south of the Orlock Bridge Fault (Fig. 7.1). The extension of the Tellus project into the border counties of Ireland provides the opportunity to complement and

\footnotetext{
${ }^{\prime}$ Ulster University, Coleraine.

${ }^{2}$ Geological Survey of Northern Ireland, Belfast.

${ }^{3}$ AJS Geoscience Consulting, Edinburgh.
} 


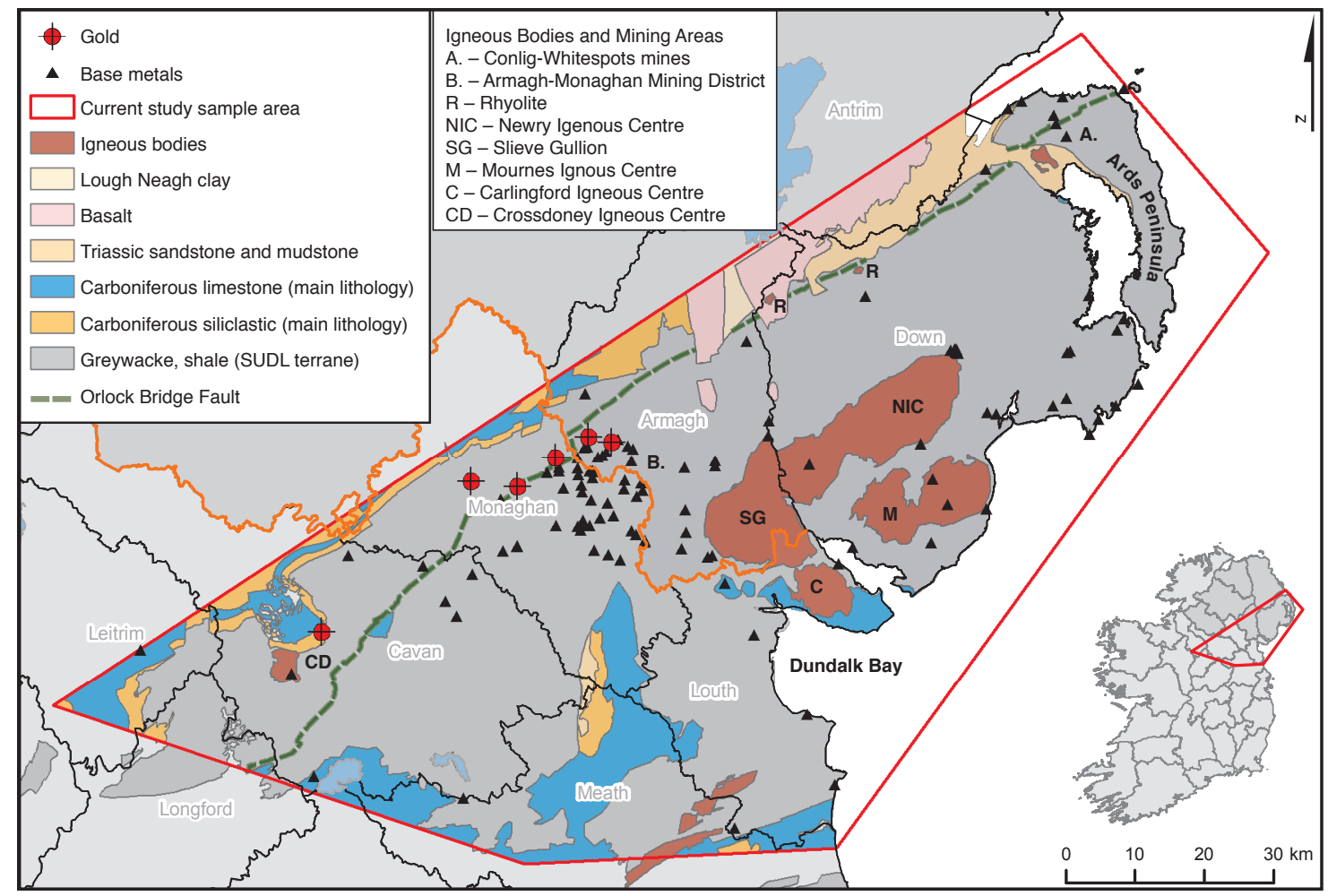

expand on this work by using soil geochemistry to investigate the distribution of gold and base metals across almost the whole outcrop of the SUDL terrane in Ireland.

\section{GLACIAL HISTORY AND DRIFT PROSPECTING}

Prospecting in glaciated areas by chemical analysis of glacial deposits has been applied with success in Canada and Finland for many years. The principal glacial material sampled is till, which forms at the base of ice sheets from rock entrained, crushed and transported by the ice. It is this process that disperses target minerals away from their bedrock source, perhaps for considerable distances in the direction of ice flow (Miller, 1984). These dispersal patterns (or 'plumes') can be simple linear features formed from single ice flow directions, or be fan or less distinctly shaped if they are a composite of more than one ice flow direction. Plumes can be detected and mapped by geochemical sampling and analysis of glacial sediments over areas much larger than the bedrock source. Combining geochemical surveys with knowledge of glacial history has allowed mineralisation to be located in regions with little or no surface rock outcrop.

Ireland was entirely covered by ice during the Last Glacial Maximum, when the ice sheets were most widely extended. The ice flowed in many different directions, evidence of which is recorded in the modern landscape. The flow patterns have been categorised into specific ice flow events (referred to as 'flow sets') by recent research based on the
Figure 7.1. Geology, sites of historic and current gold and base metal extraction and counties in the study area. Bedrock boundaries based on 1:250,000 bedrock map of Northern Ireland (GSNI, 1997) and 1:100,000 bedrock map of Ireland (GSI, 2003).

Mineral occurrences extracted from GSNI and GSI databases. 


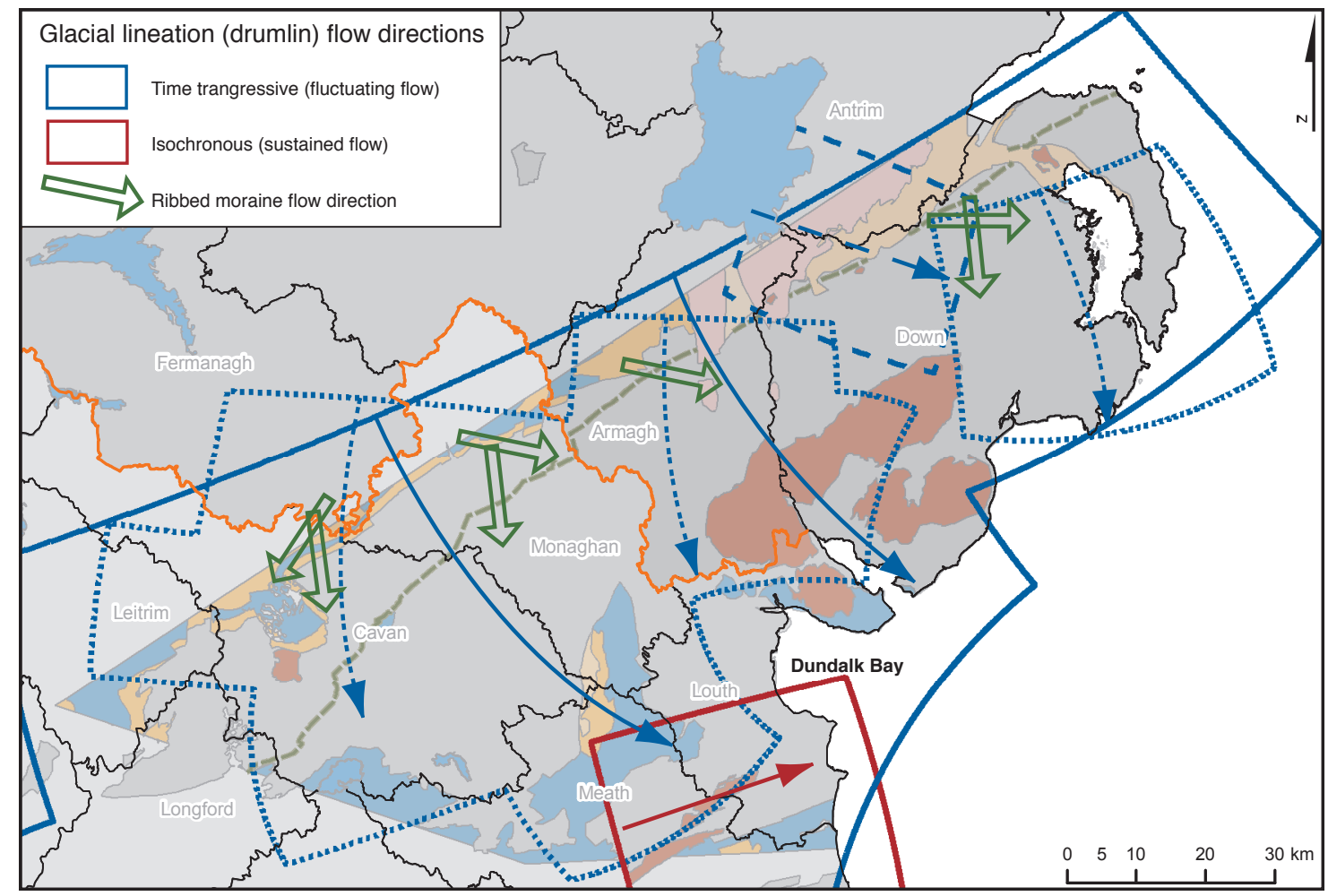

Figure 7.2. Ice flow directions over the study area. Blue represents time-transgressive and red represents isochronous drumlin flow sets with associated arrows showing ice flow directions. There are three time-transgressive flow sets represented by 1 . solid, 2. dashed and 3. dotted blue lines and arrows. Large green arrows denote flow directions

from ribbed moraines (after Greenwood and Clark, 2009). morphology of glacial landforms, specifically drumlins that formed parallel to ice flow direction (e.g. Greenwood and Clark, 2009). Flow sets based on drumlins are described as either 'time-transgressive', indicating a change in the flow direction over time, or 'isochronous', where the ice flowed in a single sustained direction. There are three time-transgressive and one isochronous drumlin flow sets in the study area (Fig. 7.2). Also, the presence of ribbed moraines, which form perpendicular to ice flow, provides further evidence of ice flow directions that predate drumlin formation. The dominant glacial sediment deposited in north Ireland is till, which over the SUDL terrane can be up to $30 \mathrm{~m}$ thick (GSNI, 1991). The main ice flow direction over the SUDL terrane was to the south and south-east (Greenwood and Clark, 2009) (Fig. 7.2). It may be expected therefore that mineral-rich material in the SUDL terrane would be dispersed in this direction from bedrock host localities.

The geochemistry of soil developed on till can be effectively used as a proxy for the till geochemistry (Dempster et al., 2013) and the Tellus surveys provide soil geochemical data that can be used to study the composition of glacial sediments that are not widely exposed in the region. This chapter applies a multivariate statistical approach to the geochemistry of soil samples taken on till to determine if it can provide further information on the occurrence and potential glacial dispersal of minerals across the region. 


\section{MeTHOD}

Topsoil samples from areas of till within the flow sets that contain the SUDL terrane were selected from the Tellus and Tellus Border data. Gold (Au) was not analysed in the topsoil samples, so the results for the metals, semi-metals and gold pathfinder elements in the topsoil were used in the statistical analysis. These were: silver (Ag), arsenic (As), bismuth (Bi), cadmium $(\mathrm{Cd})$, copper $(\mathrm{Cu})$, molybdenum $(\mathrm{Mo})$, niobium $(\mathrm{Nb})$, lead $(\mathrm{Pb})$, tin $(\mathrm{Sn})$, antimony $(\mathrm{Sb})$ and zinc $(\mathrm{Zn})$. Pathfinder elements are those that are relatively mobile and have a close relationship with the exploration target mineral (in this case gold) and may be present in greater quantities so are more readily detected in the soil samples.

Principal component analysis (PCA), a multivariate statistical technique commonly used to study variability in large geochemical data sets, was used to aid interpretation. From large data sets PCA produces a smaller number of artificial variables, called principal components (PCs), that contain information on how elements are related within the whole data set.

PCA produces principal component loadings that describe the relative significance of each chemical element in the data set. The element loading values determine a score that can be assigned to the soil sample's location, so that groupings of high loading elements at a sample point give high scores. The scores therefore reflect the element groupings most closely associated with the sample point. For example, if the common gold pathfinder elements Ag, As and Bi were the three highest loadings in a given PC, the sample points with the highest scores would have a strong association with these elements, and thus potentially also with gold. The PC scores produced from the data at each sample point were subjected to natural neighbour interpolation to produce maps that show the distribution of the groups of linked elements.

The following section presents the results of PCA of metals, semi-metals and pathfinder elements from the combined Tellus and Tellus Border data set for almost the entire Irish outcrop of the SUDL terrane. This examines whether or not a multivariate statistical approach using soil geochemical data can inform gold prospecting in the north of Ireland. It also acts as an independent means to investigate the mineral prospectivity of the study area and, as the region is covered by thick $(>30 \mathrm{~m})$ till deposits, it serves to determine if the element groups identified exhibit glacially influenced dispersal patterns.

\section{RESULTS}

In the study area, 2089 samples are from soils developed on till. The first three PCs were the most significant for the selected data, accounting for $63.9 \%$ of variance, and these PCs are discussed here. On the maps, the areas that represent the high loading element associations are dark orange.

Data for Au in topsoil are not yet available for the Tellus Border survey areas (counties Monaghan and Cavan in this study), so a direct comparison of the PCA results with $\mathrm{Au}$ quantities in shallow soils is not possible. However, data are available for Au in stream 


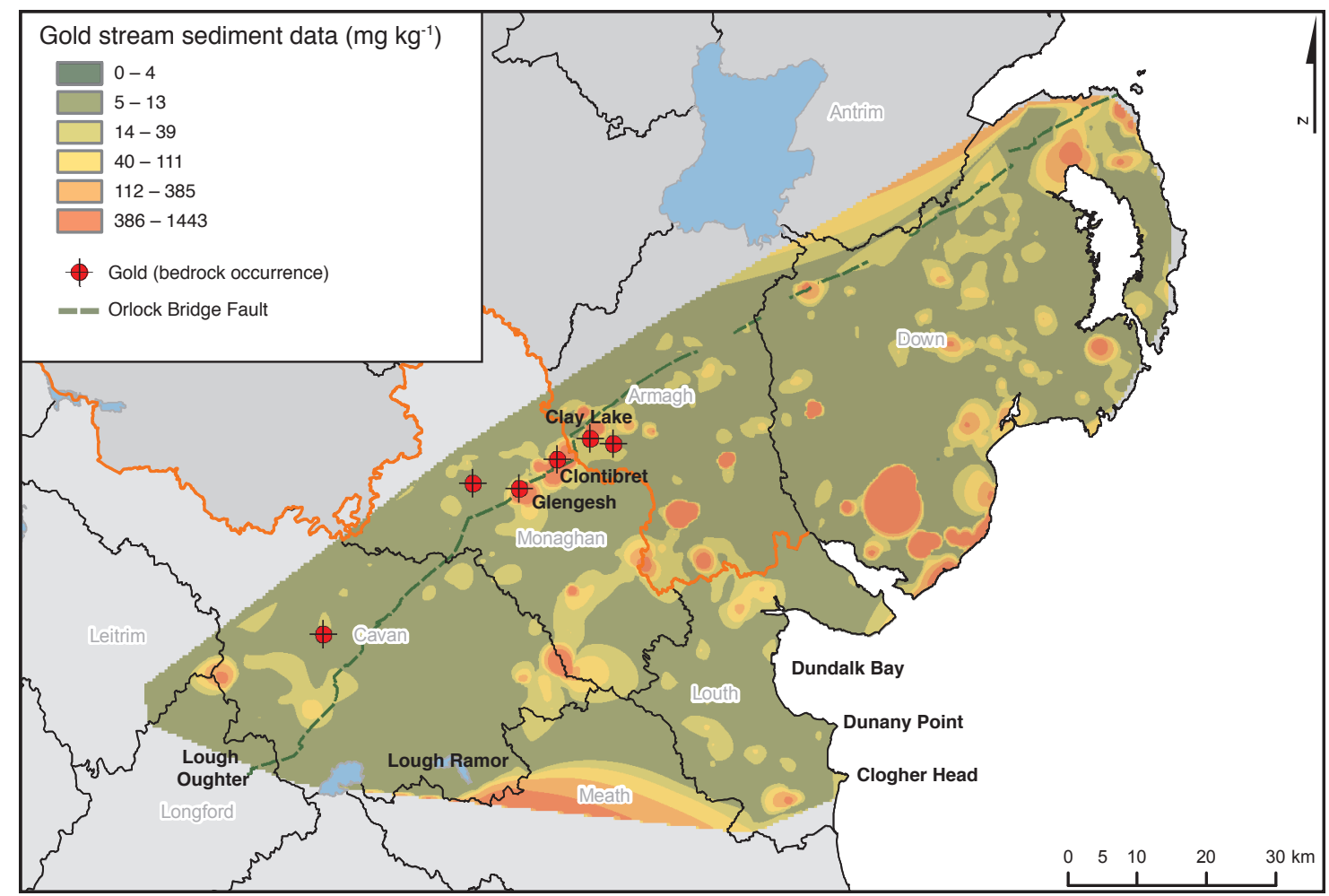

Figure 7.3. Gold distribution (interpolated) in stream sediments on the SUDL terrane outcrop. sediments and are presented in Fig. 7.3. These data were subjected to natural neighbour interpolation and are presented with the same gradational colour scheme as the PCA results. However, this is a different sample medium from soil developed on till and streams developed in post-glacial times do not represent primary dispersal, though it provides a useful comparison with the PCA results.

\section{Principal component 1}

The high loading element group $\mathrm{Pb}, \mathrm{Ag}$, As and Bi (Fig. 7.4) support the presence of $\mathrm{Au}$ as these elements are commonly associated with $\mathrm{Au}$ in a variety of geological settings (e.g. Stone et al., 1993). Figure 7.5 shows high scores in north Down, located over the Conlig-Whitespots lead mining area (Fig. 7.1) and extending further east, west and south. However, $\mathrm{Pb}$ and $\mathrm{Ag}$ can show a strong association in certain geological settings without there being significant $\mathrm{Au}$ enrichment, and indeed there is no evidence of such enrichment in the Conlig-Whitespots mineralisation. An extension of high scores is observed to the south of Slieve Gullion aligned north-west to south-east, parallel to the dominant ice flow direction. $\mathrm{A} \mathrm{Pb}, \mathrm{Zn}$ and $\mathrm{Cu}$ prospect has been previously identified in the Ballinfuil townland at the north-western end of this feature. This feature may be interpreted here as a linear dispersal plume of metallic minerals, potentially including gold, and may reflect transport associated with the Armagh Ice Stream (McCabe and Dunlop, 2006). It 

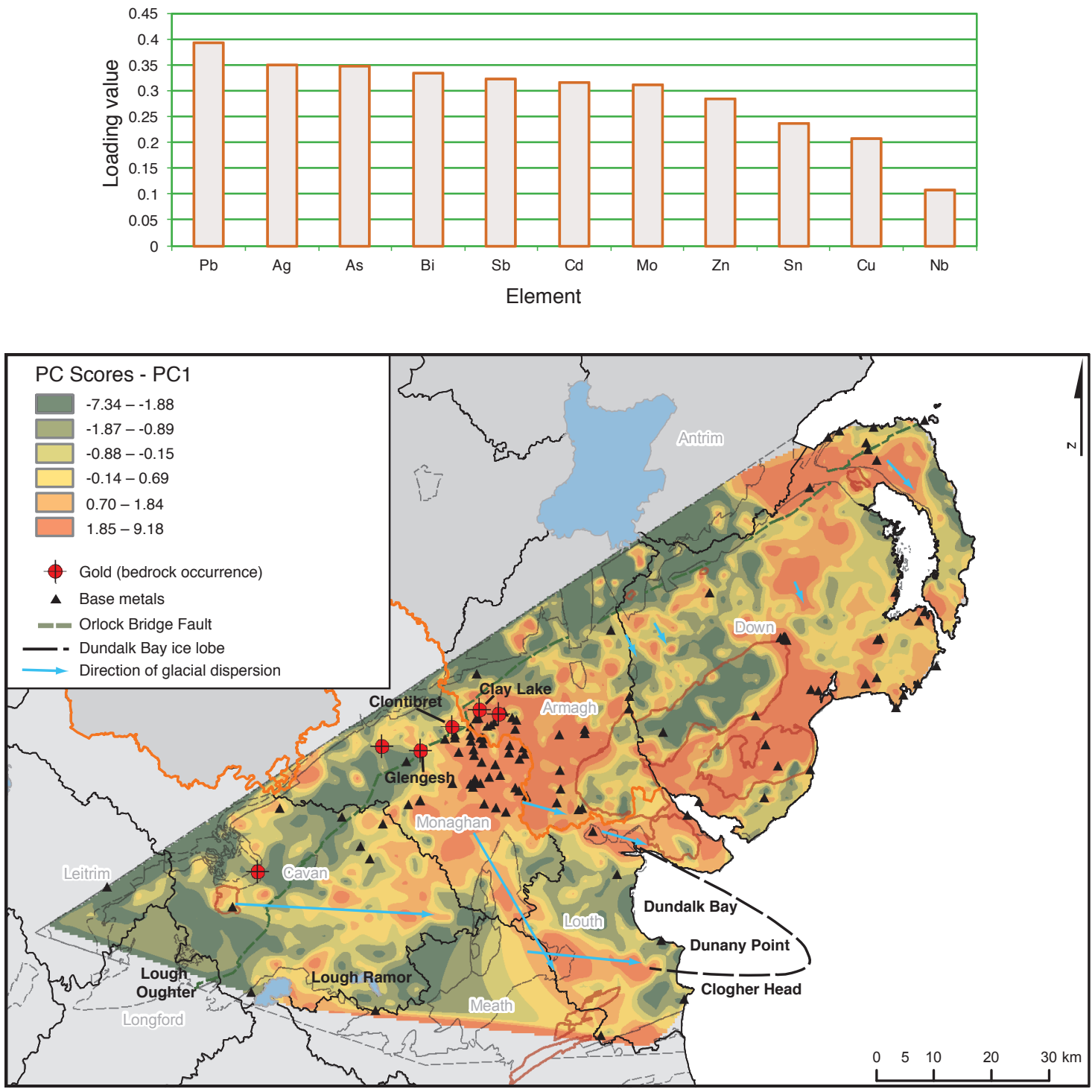

shows a close association with the Carboniferous limestone outcrop in this region also and is truncated at the coast, suggesting it continues offshore. Further south-west, a second plume extends south-east before trending east toward Dunany Point/Clogher Head. This suggests composite mineral dispersal from and parallel to two different ice flow directions from the north-west and west (Fig. 7.5).

These two distribution patterns are parallel and occur at either side of Dundalk Bay. An ice lobe readvanced into Dundalk Bay during the Killard Point Stadial and its margins were in a similar position on either side of the bay (Fig. 7.5) (McCabe and Dunlop, 2006),
Figure 7.4. Element loadings for principal component 1 , SUDL terrane metals and pathfinder elements.

Figure 7.5. Principal component 1 score distribution (interpolated) for SUDL terrane metals and pathfinder elements. 
PC2
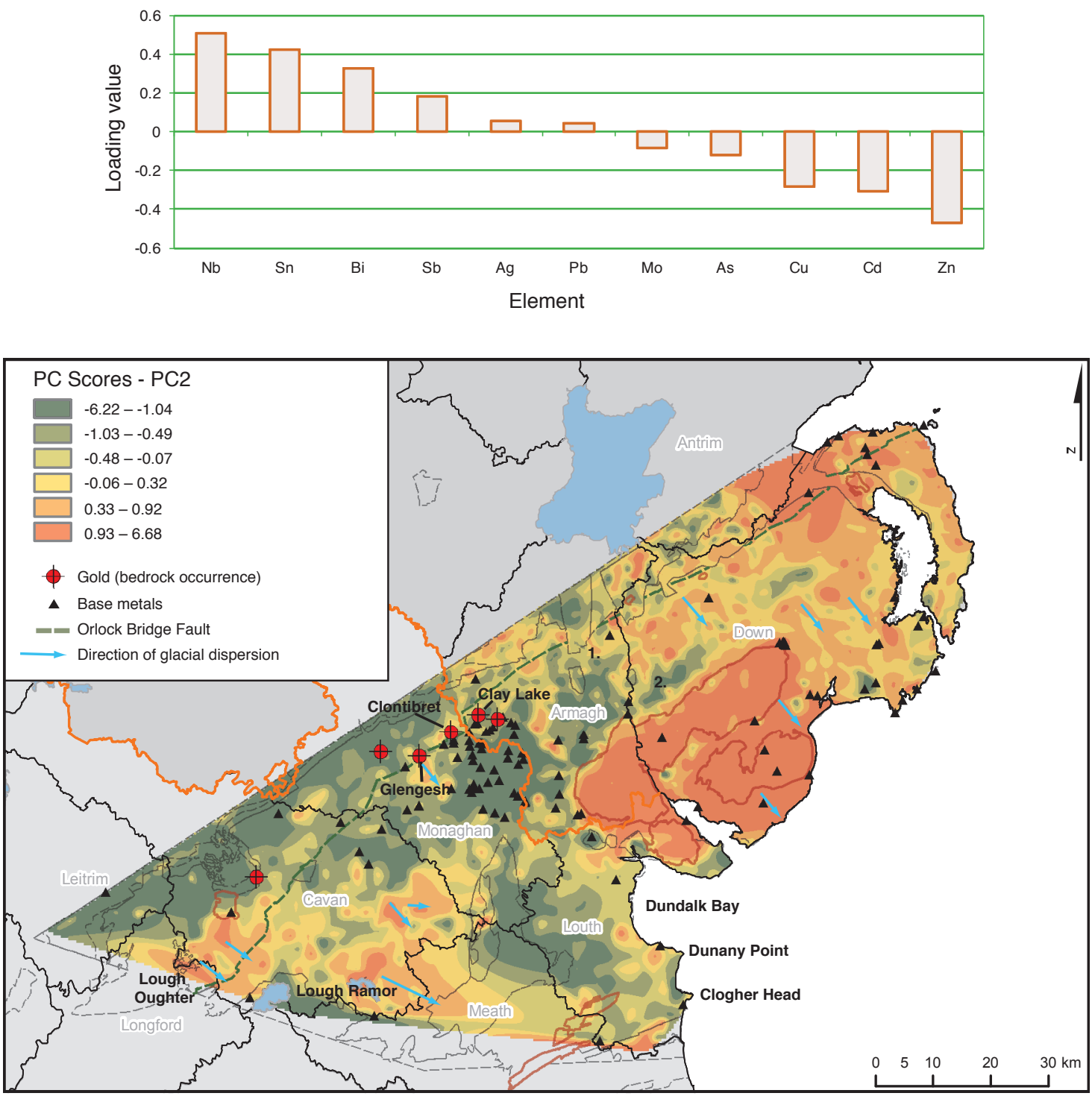

Figure 7.6. Element loadings for principal component 2 , SUDL terrane metals and pathfinder elements.

Figure 7.7. Principal component 2 score distribution (interpolated) for SUDL terrane metals and pathfinder elements. so the pattern may also be interpreted as having formed from removal of mineral-rich till in the central area where the ice flowed at greater velocity.

\section{Principal component 2}

The element loadings for this PC are shown in Fig. 7.6. Nb, Sn and Bi are typically enriched in felsic igneous rocks and shales and $\mathrm{Bi}$ is also associated with $\mathrm{Sn}$ and Au mineralisation. Enrichment in felsic rocks explains the close association seen in the PC score distribution with the granodiorites of the Late Caledonian Newry Igneous Complex and granites of 
Palaeogene Mourne Mountains Complex (Cooper and Johnston, 2004a, 2004b; Moore et al., Chapter 9, this volume) (Fig. 7.7). The high scores associated with these igneous centres extend south-eastwards from their outcrop, indicating transport parallel to the dominant ice flow direction. Many of the higher scoring areas exhibit a subtle north-west/south-east alignment in the north and central regions of the sample area, for example at the ConligWhitespots mine and east of the Newry and Mournes igneous centres. However, in the central-north region, the score distribution pattern may be influenced by glacial transport of Triassic-derived sediment from the Lagan Valley south-west of Belfast (Fig. 7.1).

In the south-west there is an area of high scores to the south and south-east of the Crossdoney intrusion. This could represent composite dispersal of mineral-rich material first of all to the south, then the south-east. To the south-west is a north-west/south-east aligned attenuated zone of high scores around Lough Oughter that strongly suggests a glacial influence. Also at Lough Ramor the high scores show a triangular pattern parallel to ice flow direction in the area.

\section{Principal component 3}

Figure 7.8 shows As, $\mathrm{Sb}, \mathrm{Mo}$ and $\mathrm{Bi}$ as the highest loading elements. The association of $\mathrm{As}, \mathrm{Sb}$ and $\mathrm{Mo}$ is indicative of Au mineralisation and the concentrations in north County Down and counties Armagh and Monaghan correlate well with known deposits of Au and base metal mineralisation (Lusty et al., 2012) (Fig. 7.9). The Clay Lake to Glenish anomaly (outlined in red) is linear (south-west to north-east) and perpendicular to known ice flow across the area. This suggests one of two scenarios: (1) it is associated with a bedrock source of similar width with little or no dispersal, suggesting that the pathfinders are penetrating through up to $30 \mathrm{~m}$ of glacial cover from the mineralised bedrock; or (2) the bedrock source is even narrower and there is some north-west to south-east dispersal. To the southeast of this anomaly is another similarly aligned area of high scores that hints at Au mineralisation (outlined in red). This is part of a north-east to south-west trending band of high scoring patches that extend across the sample area, parallel to the tract boundaries of the SUDL terrane. High scores are also found in very close association with the Mournes igneous centre, which correlates with elevated As shown by the Tellus survey in the northern Mournes and the recent findings of As-rich mineralisation in this area reported by Moore et al. (Chapter 9, this volume). Alluvial gold and bedrock Bi (with tungsten) is also known in the western side of the Mournes (Chapman et al., 2000; Moles et al., 2013). It is worth noting that the base metal and gold occurrences in this PC appear to be almost totally mutually exclusive. At Crossdoney there again appears to be a southward extending plume with its origin in the igneous body.

\section{DisCUSSION}

For the SUDL terrane, the sample area for the current study was selected based on outcrop extent and sample availability and it includes the area investigated by Lusty et al. (2012). 

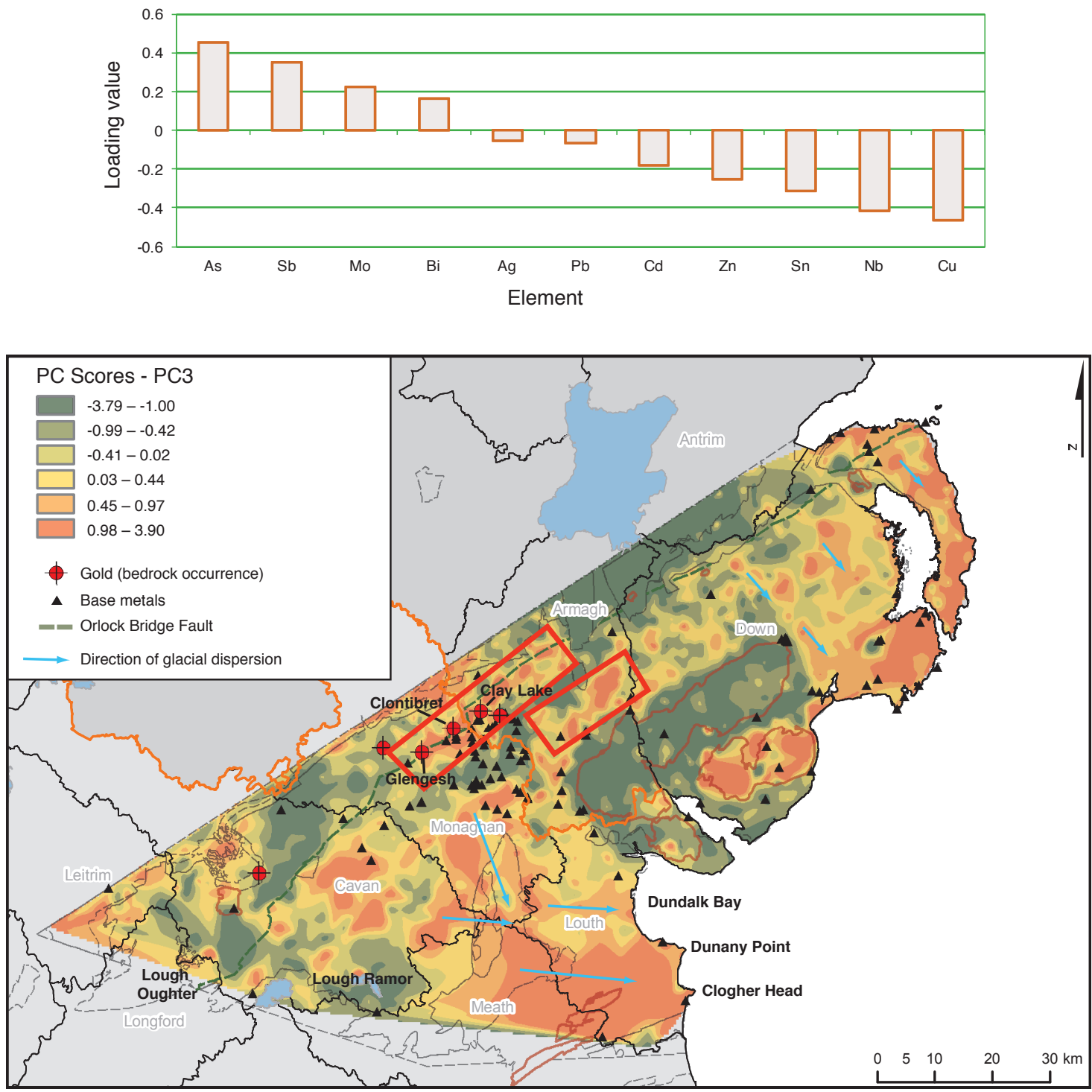

Figure 7.8. Element loadings for principal component 3 , SUDL terrane metals and pathfinder elements.

Figure 7.9. Principal component 3 score distribution (interpolated) for SUDL terrane metals and pathfinder elements.
There is evidence in the results for glacial dispersal patterns of base metals and gold pathfinder elements from known sources and the results also highlight areas of potential gold mineralisation not yet exploited in the study area.

The spatial distribution of element groups and areas of potential mineral exploitation do in places exhibit spatial patterns strongly or subtly influenced by glacial flow events, as either simple ribbon or composite dispersal plumes. The flow directions identified are parallel to the ice flow directions derived from geomorphology (the flow sets) so the results also complement the ice sheet model of Greenwood and Clark (2009). Transport distances 
are relatively short $(\leq 20 \mathrm{~km})$, in contrast to the long mineral-rich plumes $(\geq 70 \mathrm{~km})$ identified in Canada, for example. Au distribution in the SUDL terrane is therefore determined in the first instance by bedrock and the results show distribution consistent with ice flow direction in the till. This finding supports that of predominantly locally derived till with short transport distances for this sector of the Irish Ice Sheet as presented in Dempster $e t$ al. (2013) and discussed in Breward et al. (2011). It also correlates with a local source and short transport distance for Au in the Mournes area, as proposed by Moles et al. (2013).

It is clear that the areas of potentially high prospectivity derived from PCA include the known deposits in the Armagh-Monaghan mining district and the Conlig-Whitespots mine area. These areas are also identified as prospective by Lusty et al. (2012), so there is good correlation between the studies for these localities, which confirms that PCA of soil geochemistry can be used to identify gold prospective areas in the region. The potentially high prospectivity areas also correlate well with the Au content of stream sediments presented in Fig. 7.3, particularly with PC3.

\section{Conclusion}

The spatial distribution patterns for the metals, semi-metals and gold pathfinder elements in the outcrop of the SUDL terrane show different areas with potential gold mineralisation. The results demonstrate that PCA of soil geochemistry is able independently to identify areas of potential metallic mineralisation that correlate well with known occurrences in the SUDL terrane, so it is also able to identify favoured areas for exploration. Both simple ribbon and composite glacial dispersal patterns are identified and transport paths indicate that dispersal is parallel to ice flow directions interpreted from geomorphology. Transport distances in all cases are relatively low $(\leq 20 \mathrm{~km})$.

The results demonstrate that PCA of regional soil geochemical data can make a valid contribution to base metal and gold prospecting. The successful identification of known deposits and further potential source areas indicates that PCA of shallow soil geochemistry could usefully be integrated with other prospectivity investigations to define target areas in the north of Ireland and other areas of glaciated terrain.

\section{ACKNOWLEDGEMENTS}

MRC publishes with the permission of the Executive Director of the British Geological Survey (NERC).

\section{REFERENCES}

Anderson, T.B., 2004 'Southern Uplands - Down-Longford terrane', in W.I. Mitchell (ed.), The Geology of Northern Ireland: Our Natural Foundation. Second edition, 41-60. Belfast. Geological Survey of Northern Ireland.

Arthurs, J.W. and Earls, G., 2004 'Minerals' in W.I. Mitchell (ed.), The Geology of Northern Ireland: Our Natural Foundation. Second edition, 255-72. Belfast. Geological Survey of Northern Ireland. 
Breward, N., Stone, P., Flight, D. and Anderson, T.B., 2011 'Regional geochemical comparisons from the Lower Palaeozoic, Southern Uplands - Down-Longford terrane in Northern Ireland and Scotland', Scottish Journal of Geology, 47, 33-43. Available at http://nora.nerc.ac.uk/15351/. http://dx.doi.org/10.1144/0036-9276/01-410.

Chapman, R.J., Leake, R.C. and Moles, N.R., 2000 'The use of microchemical analysis of alluvial gold grains in mineral exploration: experiences in Britain and Ireland', Journal of Geochemical Exploration, 71, 241-68.

Cooper, M.R. and Johnston, T.P., 2004a 'Late Palaeozoic intrusives', in W.I. Mitchell (ed.), The Geology of Northern Ireland: Our Natural Foundation. Second edition, 61-8. Belfast. Geological Survey of Northern Ireland.

Cooper, M.R. and Johnston,T.P., 2004b 'Palaeogene intrusive igneous rocks', in W.I. Mitchell (ed.), The Geology of Northern Ireland: Our Natural Foundation. Second Edition, 179-98. Belfast. Geological Survey of Northern Ireland.

Dempster, M., Dunlop, P., Cooper, M.R. and Scheib, A.J., 2013 'Principal component analysis of the geochemistry of soil developed on till in Northern Ireland', Journal of Maps, 9, 373-89. Available at http://nora.nerc.ac.uk/503933/. http://dx.doi.org/10.1080/17445647.2013.789414.

Geological Survey of Ireland (GSI), 2003 1:100,000 Bedrock Map Series. Dublin. Geological Survey of Ireland.

Geological Survey of Northern Ireland (GSNI), 1991 Geological Map of Northern Ireland (Quaternary), 1:250,000. Belfast. Geological Survey of Northern Ireland.

Geological Survey of Northern Ireland (GSNI), 1997 Geological Map of Northern Ireland (Solid), 1:250,000. Belfast. Geological Survey of Northern Ireland.

Greenwood, S.L. and Clark, C.D., 2009 'Reconstructing the last Irish Ice Sheet 2: a geomorphologically-driven model of ice sheet growth, retreat and dynamics', Quaternary Science Reviews, 28, 3101-23.

Lusty, P.A.J., Scheib, C., Gunn, A.G. and Walker, A.S.D., 2012 'Reconnaissance scale prospectivity analysis for gold mineralisation in the Southern Uplands - Down-Longford Terrane, Northern Ireland', Natural Resources Research, 21, 359-82. Available at http://nora.nerc.ac.uk/18864/. http://dx.doi.org/10.1007/s11053-012-9183-3.

McCabe, A.M. and Dunlop, P., 2006 The Last Glacial Termination in Northern Ireland. Belfast. Geological Survey of Northern Ireland.

Miller, J.K., 1984 'Model for clastic indicator trains in till', in Prospecting in Areas of Glaciated Terrain, 69-77. London. Institution of Mining and Metallurgy.

Moles, N.R., Chapman, R.J. and Warner, R.B., 2013 'The significance of copper concentrations in natural gold alloy for reconnaissance exploration and understanding gold-depositing hydrothermal systems', Geochemistry: Exploration, Environment, Analysis, 13, 115-30.

Stone, P., Green, P.M., Lintern, B.C., Simpson, P.R. and Plant, J.A., 1993 'Regional geochemical variation across the Iapetus Suture zone: tectonic implications', Scottish Journal of Geology, 29, $113-21$. 
Unearthed: impacts of the Tellus surveys of the north of Ireland

First published in 2016 by the

Royal Irish Academy

19 Dawson Street

Dublin 2

www.ria.ie

Copyright (C) 2016 Royal Irish Academy

ISBN: 978-1-908996-88-6

The articles in this book are open access and distributed under the terms of the Creative Commons Attribution 4.0 licence, which permits unrestricted use, distribution and reproduction in any medium, provided the original authors and source are credited. To view a copy of this licence, visit https://creativecommons.org/licenses/by/4.0/

Except where noted:

Geological mapping for Northern Ireland / Tellus data are provided by the Geological Survey of Northern Ireland.

Geological mapping for Ireland / Tellus Border data are provided by the Geological Survey of Ireland.

Topographic mapping for Northern Ireland is derived from Land and Propery Services Open Data and contains public sector information licensed under the Open Government Licence v3.0. (http://www.nationalarchives.gov.uk/doc/open-governmentlicence/version/3/).

Topographic mapping for Ireland is derived from Ordnance Survey of Ireland Open Data (https://creativecommons.org/licenses/by/4.0/legalcode).

While every effort has been made to contact and obtain permission from holders of copyright, if any involuntary infringement of copyright has occurred, sincere apologies are offered, and the owner of such copyright is requested to contact the publisher.

British Library Cataloguing-in-Publication Data. A catalogue record is available from the British Library.

Design: Alex Donald, Geological Survey of Northern Ireland.

Index: Brendan O'Brien.

Printed in Poland by L\&C Printing Group. 


\section{Table of Contents:}

\section{Prelim}

DOI: https://doi.org/10.7486/DRI.b851k323d

\section{Chapter 1}

The Tellus geosciences surveys of the north of Ireland: context, delivery and impacts

DOI: https://doi.org/10.7486/DRI.st74s528d

\section{Chapter 2}

The Tellus airborne geophysical surveys and results DOI: https://doi.org/10.7486/DRI.t148tx96z

\section{Chapter 3}

The Tellus geochemical surveys, results and applications

DOI: https://doi.org/10.7486/DRI.t722wq645

\section{Chapter 4}

Stakeholder engagement for regional geoscientific surveying: the Tellus Border communications campaign

DOI: https://doi.org/10.7486/DRI.w089fr763

\section{Chapter 5}

Mineral resources and Tellus: the essential balance DOI: https://doi.org/10.7486/DRI.wd37kb12s

\section{Chapter 6}

Gold exploration in the north of Ireland: new targets from the Tellus Projects

DOI: https://doi.org/10.7486/DRI.wh24m696v

\section{Chapter 7}

Using soil geochemistry to investigate gold and base metal distribution and dispersal in the glaciated north of Ireland

DOI: https://doi.org/10.7486/DRI.wm11n3806

\section{Chapter 8}

Critical metals for hightechnology applications: mineral exploration potential in the north of Ireland DOI: https://doi.org/10.7486/DRI.wp98p0649

\section{Chapter 9}

A natural laboratory for critical metals investigations in the Mourne Mountains granites

DOI: https://doi.org/10.7486/DRI.cc08ww45f

\section{Chapter 10}

Geothermal potential of granitic rocks of the Mourne Mountains

DOI: https://doi.org/10.7486/DRI.ff36jm09f

\section{Chapter 11}

Shape and intrusion history of the Late Caledonian

Newry Igneous Complex, Northern Ireland

DOI: https://doi.org/10.7486/DRI.2v248822m

\section{Chapter 12}

Using Tellus data to enhance targeting of volcanogenic massive sulphide mineralisation in the Tyrone Igneous Complex

DOI: https://doi.org/10.7486/DRI.5x226w262

\section{Chapter 13}

The geological significance of electrical conductivity anomalies of the Ordovician- Silurian Moffat Shale Group, Northern Ireland

DOI: https://doi.org/10.7486/DRI.6m31f4149

\section{Chapter 14}

Faults, intrusions and flood basalts: the Cenozoic structure of the north of Ireland

DOI: https://doi.org/10.7486/DRI.90205h306

\section{Chapter 15}

Information for agriculture from regional geochemical surveys: the example of soil $\mathrm{pH}$ in the Tellus and Tellus Border data

DOI: https://doi.org/10.7486/DRI.dv14c8060

\section{Chapter 16}

An ecohydrological investigation of wetlands in the border counties of Ireland: a framework for a holistic understanding of wetland systems DOI: https://doi.org/10.7486/DRI.hd775d90j 
Chapter 17

Assessing nutrient enrichment risk to groundwaterdependent ecosystems in the border counties of Ireland DOI: https://doi.org/10.7486/DRI.k356pk18j

\section{Chapter 18}

Mapping the terrestrial gamma radiation dose

DOI: https://doi.org/10.7486/DRI.k930rb86z

\section{Chapter 19}

Soils and their radiometric characteristics

DOI: https://doi.org/10.7486/DRI.mp495t62g

\section{Chapter 20}

Modelling in-house radon potential using Tellus data and geology to supplement inhouse radon measurements

DOI: https://doi.org/10.7486/DRI.ns06hm86z

\section{Chapter 21}

Determining geochemical threshold values from the Tellus data sets: the examples of zinc and iodine| DOI: https://doi.org/10.7486/DRI.r2087418g

\section{Chapter 22}

Identification of the geochemical signatures of diffuse pollution in the Tellus Border soil data set, using source apportionment

DOI: https://doi.org/10.7486/DRI.wh24m698d

\section{Chapter 23}

Stream sediment background concentrations in mineralised catchments in Northern Ireland: assessment of 'pressures' on water bodies in fulfilment of Water Framework Directive objectives DOI: https://doi.org/10.7486/DRI.x633tf86g

\section{Chapter 24}

Mapping metallic contamination of soils in the Lower Foyle catchment

DOI: https://doi.org/10.7486/DRI.9k42bv355

\section{Chapter 25}

Refining the human health risk assessment process in Northern Ireland through the use of oral bioaccessibility data

DOI: https://doi.org/10.7486/DRI.9p29cr199

\section{Chapter 26}

Combining environmental and medical data sets to explore potential associations between environmental factors and health: policy implications for human health risk assessments

DOI: https://doi.org/10.7486/DRI.9s16dn03n

\section{Chapter 27}

Mapping a waste disposal site using Tellus airborne geophysical data

DOI: https://doi.org/10.7486/DRI.9w03fh87q

\section{Chapter 28}

The use of aero-magnetics to enhance a numerical groundwater model of the Lagan Valley aquifer, Northern Ireland

DOI: https://doi.org/10.7486/DRI.9z90gd711

\section{Chapter 29}

Carbon sequestration in the soils of Northern Ireland: potential based on mineralogical controls DOI: https://doi.org/10.7486/DRI.b277h9556

\section{Chapter 30}

Spatial distribution of soil geochemistry in geoforensics DOI: https://doi.org/10.7486/DRI.b564j6392

\section{End matter}

DOI: https://doi.org/10.7486/DRI.bc38m007j 